\title{
Macroeconomy and Financial Market Effects of Oil Price Changes: A Comparison of Large Net Oil- Producer and Oil-Consumer Countries*
}

\author{
M. Ali Sotoudeh ${ }^{1,2}$ \\ Andrew C. Worthington ${ }^{2}$
}

\begin{abstract}
This paper considers variation in the effects of oil price changes on the economies of large net oil-producer and large net oil-consumer countries using a bias-corrected, least squares dummy variable approach, Granger causality tests, and monthly data from May 1986 to January 2013. We find that oil prices Granger-cause most macro aspects of net oil producers but not those of net oil consumers. In contrast, oil prices exert a greater influence on financial markets in net oil consumers than in net oil producers. Overall, we identify substantial differences in the responses of the macroeconomy and financial markets to oil price changes in the two groups of countries.
\end{abstract}

Keywords: financial markets, macroeconomy, oil prices, panel linear causality.

\section{Introduction}

The literature on the macroeconomic and financial market effects of oil price changes reveals mixed findings arising from differences in estimation method, the identification of shocks, the specification of variables, the sampling of countries and period, usually on a country-bycountry basis. One point of distinction in this body of research is between oil-importing countries and oil-exporting countries, that is, between countries that import or export large volumes of oil. The conventional (and rather simple) argument is that depending on the structure of their economies, the macroeconomies and financial markets of oil importers (exporters) will suffer (benefit) from oil price increases and vice versa for oil price decreases. For instance, among oil importers, lower oil prices are similar to a tax cut, which increase consumer disposable income and lower the cost of production. With the increased cash flows, lower interest rates as well as lower inflation are reflected in greater economic activity, higher share prices, increasing industrial production, and ultimately, higher economic growth.

\footnotetext{
* The authors would like to thank two anonymous referees and delegates at the 2014 Australian Conference of Economists in Hobart for their helpful comments and suggestions.

${ }^{1}$ Department of Economics, University of Sistan and Baluchestan, Zahedan, Iran

2 Department of Accounting, Finance and Economics, Griffith University, Brisbane, Australia JEL classifications: C23, C33, G10, Q43

Correspondence: Department of Accounting, Finance and Economics, Griffith University, 170 Kessels Road, Nathan, QLD 4111, Australia. Email: a.worthington@griffith.edu.au
} 
The same process works in the opposite direction for higher oil prices and in reverse for oil producers.

Invariably, the former includes countries like the US, China, Japan, India, Germany and South Korea and the latter countries like Saudi Arabia, Russia, the United Arab Emirates, Kuwait, Nigeria, and Iran. However, this distinction is not always clear and does not accurately reflect the potential impact of oil price changes given the disjunction between oil production and exporting and oil consumption and importing. For example, only 11 of the world's 15 leading oil-producer countries are also leading oil-exporters, yet few would deny that oil prices would still affect their economies, and certainly in different ways for a country that exported with a relatively low level of domestic consumption or one that exported with a high level of domestic consumption. Likewise, despite itself being a leading oil producer, the US is also the largest oil importer. In fact, altogether five of the 15 leading oil producers are also among the leading oil consumers. Surely, the economies and financial markets of these countries will react differently according to whether they are a large oil producer and a small oil consumer or a large oil consumer and a large oil producer.

In terms of related research, oil-producer countries can arguably benefit from oil price shocks, while the effects on oil-consumer countries are generally more complicated (e.g., Korhonen \& Ledyaeva 2010). There is also evidence concerning the heterogeneity of the causal effects of oil price movements on industrial production (e.g., Lee \& Ni 2002, JiménezRodríguez 2011). Where industrial production is widely used as proxy for economic activity, such results indicate the existence of indirect effects during transmission of the oil price changes — in both oil-consumer and oil-producer countries - which affect the total influence of oil price changes on an economy. Of the many possible contributing factors, macroeconomic structure is important (Jiménez-Rodríguez 2011, Schubert \& Turnovsky 2011). Likewise, other studies demonstrate the adverse effects of oil price movements on economic performance generally (Cunado \& Perez de Gracia 2005, Elmi \& Jahadi 2011, Mork et al. 1994 and Nandha \& Brooks 2009).

Elsewhere, while oil price shocks affect financial markets nonlinearly (Apergis \& Miller 2009 and Ciner 2001), any indirect effects of the oil price changes may weaken these direct effects. For instance, Apergis and Miller (2009) show that oil price changes explain just over 12 per cent of stock prices. Financial market responses to the oil price movements are also not necessarily the same across countries. For instance, Park and Ratti (2008) show that acceleration in the world real oil price raises short-term interest rates in the US and 8 of 13 European countries with a delay of one or two months, and provide evidence of a symmetric effect on real stock returns in oil-importing countries, but none on the US or Norway. However, there is more evidence on the adverse responses of financial markets to oil price movements (for example, Abu-Bader \& Abu-Qarn 2008, Ayhan Kapusuzoglu 2011, Biswas 2008, Boulila \& Trabelsi 2004, Sanchez \& Hassan 2011 and Wolde-Rufael 2009). Altogether, financial markets, and especially interest rates, are known to be important channels in transferring the effects of oil price changes to GDP (see e.g., Balke et al. 2002, Bohi 1991, Finn 2000 and Keane \& Prasad 1996).

Accordingly, in this paper, rather than the rather blunt and misleading distinction between large oil exporters and large oil importers in existing analyses, we focus instead on significant net oil production and consumption as measured by the share of GDP. We also aim to correct the existing imbalance in findings given the usual focus on oil importers (here net consumers) and not on oil exporters (here net producers), mainly because reliable and consistent data are usually more difficult to obtain for the latter. To compare the direct causal effects of global oil price changes on the economies of net oil-consumer and net oil-producer countries, we employ a least-biased econometric approach. Utilizing a dynamic panel 
approach enables us to consider the endogenous behaviour of variables, which is not possible using a simple country-by-country model.

The remainder of the paper is structured as follows. Section 2 discusses the data. Sections 3 and 4 detail the method and discuss the estimation results, respectively. Section 5 provides some brief concluding remarks.

\section{Data description}

Our sample data consist of global oil prices and selected macroeconomic and financial market variables for seven net oil-consumer and three net oil-producer countries. Our sample selection criterion is the share of net oil production (consumption) in GDP. As illustrated in Figure 1, we calculate this for a wide range of oil-producer and oil-consumer countries. After considering the availability of the necessary data among these countries, we designate the US, Brazil, Denmark, Italy, Germany, the Netherlands and Sweden as net oil consumers and Canada, Mexico and Norway as net oil producers. Table 1 provides summary statistics of oil production and oil consumption in the final sample of countries.

\section{$<$ FIGURE 1 ABOUT HERE $>$}

\section{$<$ TABLE 1 ABOUT HERE $>$}

We use monthly data covering the period 1986M5-2013M1. Table 2 describes the variables employed. Our variables include the global oil price $(O P)$, industrial production $(I P)$, consumer price index $(C P I)$, real exchange rate $(R E R)$, share price $(S P)$, short-term real interest rate $(I R)$ and monetary aggregate $(M A)$. Data for $C P I$, nominal exchange rate, $I P$, and $S P$ are from the Organisation for Economic Co-operation and Development (OECD). The OECD is also the source of $I R$ data for the entire sample excluding Brazil. We collect $I R$ for Brazil from the Portal de Financas website. For Canada, Denmark, Mexico, Norway, Sweden, Brazil and the US, the MA statistics -including narrow money M1 - are from the OECD website. For Germany and Italy, we collect M1 from the Deutsche Bundesbank and Banca d'Italia, respectively. As a proxy for MA in the Netherlands, we could only obtain M3 from the De Nederlandsche Bank. Finally, we use the monthly West Texas Intermediate (WTI) oil price index, available in the World Bank website. All data are indexed to the 2010 monthlyaverage.

\section{$<$ TABLE 2 ABOUT HERE $>$ \\ $<$ TABLE 3 ABOUT HERE $>$}

To test whether our panel data are stationary, we apply Im-Pesaran-Shin (IPS) and Fisher-type Augmented Dickey-Fuller (ADF) tests given their assumptions on finite sample size, which are appropriate for our sample [see Moon \& Phillips (1999) and Phillips \& Moon (2000) concerning assumptions about the required sizes of $\mathrm{N}$ and T]. Following Choi (2001) in applying Fisher-type ADF test, we estimate panel-specific unit root statistics by combining the inverse chi-square, inverse normal, inverse logit and modified inverse chi-square statistics. Additionally, we only estimate the t-bar statistic to perform the IPS test. It is worth noting that the Fisher-type ADF test is preferred to the IPS test. The results displayed in Tables 3-4 indicate that the first differences of all variables are stationary at the 1 per cent level of significance. 


\section{Empirical methodology}

\subsection{Bias-corrected LSDV model}

To investigate all possible dynamic relationships within a panel of cross sectional units, the panel vector autoregressive (PVAR) approach has widely been applied in the literature. This approach has the least bias when cross sectional units and time dimensions tend to be infinite. Thus, for the case we are studying, the finite cross sections do not allow us to employ PVAR estimators due to biased estimations. In this regard, Juessen and Linnemann (2010) have compared the widely applied techniques in estimating PVAR models with large time dimensions using Monte-Carlo simulation. They show that as all instrumental variables and generalized method of moments (GMM) estimators are severely biased in models with restricted number of cross-sectional units, bias-corrected least squares dummy variables (LSDV) model is easy to implement and is best suited for samples with a large time dimension. However, it still does not suit our case as this model employs the moderate number of panels. To consider a model with further corrections applicable for small panels, we implement the bias-corrected LSDV model demonstrated by Bruno (2005). Consider the following dynamic panel data model:

$$
y_{i t}=\gamma y_{i, t-1}+x_{i t}^{\prime} \beta+\eta_{i}+\epsilon_{i t} ; \quad|\gamma|<1 ; i=1, \ldots, N \text { and } t=1, \ldots, T
$$

In this model, $y_{i t}$ is the dependent variable, $x_{i t}$ is the $\{(k-1) \times 1\}$ vector of strictly exogenous explanatory variables, $\eta_{i}$ is an unobserved individual effect and $\epsilon_{i t}$ is an unobserved white noise disturbance with constant variance $\sigma_{\epsilon}^{2}$. Upon data collection during the time and across individual units, Equation 1 is modified as below:

$$
y=D \eta+W \delta+\epsilon
$$

where $D=I_{N} \otimes \iota_{T}$ is the $(N T \times N)$ matrix of individual dummies $\left(\iota_{T}\right.$ is the $(T \times 1)$ vector of all unity elements); $y$ and $W=\left(y_{-1}: X\right)$ are the $(N T \times 1)$ and $(N T \times k)$ matrices of stacked observations, $\eta$ is the $(N \times 1)$ vector of individual effects, $\epsilon$ is the $(N T \times 1)$ vector of disturbances; and $\delta=\left(\gamma \vdots \beta^{\prime}\right)^{\prime}$ is the $(k \times 1)$ vector of coefficients. To select the usable observations from within unbalanced panel data for our dynamic model, a selection index is designed as below:

$$
s_{i t}= \begin{cases}1 & \text { if }\left(r_{i t}, r_{i t-1}\right)=(1,1) \\ 0 & \text { otherwise }\end{cases}
$$

where $r_{i t}=1$ if $y_{i t}$ and $x_{i t}$ are observed and $r_{i t}=0$ otherwise, $i$ denotes the size of time series and $t$ refers to time dimension. Define $s_{i}=\left[s_{i 1} \ldots, s_{i T}\right]^{\prime}$ the $(T \times 1)$-vector for each $i$ and the $(T \times T)$ diagonal matrix $S_{i}$ the vector $s_{i}$ on its diagonal. Thus, the $(N T \times N T)$ block-diagonal matrix $\mathrm{S}$ is $S=\operatorname{diag}\left(S_{i}\right)$. Now, we rewrite Equation 2 using above definition as below:

$$
S y=S D \eta+S W \delta+S \epsilon
$$

In this equation, $\delta$ is the LSDV estimator, which is calculated through the following formula:

$$
\delta_{L S D V}=\left(W^{\prime} M_{S} W\right)^{-1} W^{\prime} M_{S} y
$$

where 


$$
M_{S}=S\left\{I-D\left(D^{\prime} S D\right)^{-1} D^{\prime}\right\} S
$$

is the symmetric and idempotent $(N T \times N T)$ matrix, which is removing individual means and keeping usable observations.

As explained, the above LSDV estimator is biased and we need the bias approximation term to calculate unbiased estimators. Through the estimation procedure of bias approximation term, which has been explained in detail in Bruno (2005) and Bun and Kiviet (2003), one of the Anderson and Hsiao (1982), Arellano and Bond (1991) or Blundell (1998) estimators is employed to measure bias approximation term. Assuming $B_{i}$ indicates one of such estimated bias approximations, the bias-corrected LSDV model is estimated through the following formula:

$$
L S D V C_{i}=L S D V-\hat{B}_{i}
$$

where LSDVC denotes our target bias-corrected LSDV and $i=1,2,3$ addresses one of the Anderson and Hsiao (1982), Arellano and Bond (1991) or Blundell (1998) bias approximations. Using LSDVC instead of the biased LSDV estimator, we now estimate the parameters presented in Equation 2.

\subsection{Linear causality and elasticity}

To test the linear causality between variables, the Granger (1969) causality test has widely been applied within the macroeconomic literature. There are also other linear causality tests such as the Sims test or the Modified Sims test, which are being used in economics literature as well. However, as Guilkey and Salemi (1982) show, the direct Granger causality test rejects a false null hypothesis 3.26 per cent and 2.64 per cent more than Sims and Modified Sims tests, respectively. We followed the Granger Causality test to consider the causality of oil price movements to macroeconomic and financial market variables. The direct Granger causality test, as a powerful tool, describes both the existence and direction of causality. In regression of $y_{i t}$ on lagged values of $y_{i t}$ and $O P_{t}, O P_{t}$ would not be Granger-cause of $y_{i t}$ if the coefficients of $O P_{t}$ are jointly zero. Consider the following equation:

$$
y_{i t}=\sum_{j=1}^{m} \varphi_{j} y_{i, t-i}+\sum_{j=1}^{m} \theta_{j} O P_{t-j}+D_{i t}+e_{i t}
$$

where $\varphi_{j}$ and $\theta_{j}$ are coefficients, $y_{i t}$ and $O P_{t}$ indicate the dependent variable and global oil price, respectively. $D_{i t}$ denotes deterministic trend and $e_{i t}$ is the random error term. Rejection of the null hypothesis of $\theta_{1}=\theta_{2}=\ldots=\theta_{n}=0$ indicates that $O P_{t}$ is the Granger cause of $y_{i t}$. To apply linear Granger causality test using our finite panel data model, we use the first difference of the variables (which are stationary). Furthermore, to test whether the coefficients are statistically significant, we calculate bootstrapped Chi-square statistics.

Considering Bruno (2005), we measure the oil price elasticity by estimating the following dynamic model:

$$
d \ln \left(y_{i t}\right)=\alpha \cdot d \ln \left(y_{i, t-1}\right)+\beta \cdot d \ln \left(O P_{t}\right)+u_{i}+\varepsilon_{i t}
$$

where $u_{i}$ is the individual effects while no distributional assumption is made apart from being fixed over time; and $\varepsilon_{i t}$ is independently and identically distributed (iid) over the whole panel. It is worth noting that $u_{i}$ and $\varepsilon_{i t}$ are independent for each $i$ over time. Finally, $\alpha$ and $\beta$ are 
parameters to be estimated. Using Equation $9, \beta$ is the substitutionary oil price elasticity of $y_{i t}$. It is worth noting that generally, the application of log differences of the variables causes losing some important long-term information of data at level and hence, inserting an error correction (EC) term to the Equation 6 incorporates back a great part of such missed information. However, as we only study the short-term interactions of global oil price changes with other sample variables through above Equation, explaining the long-term error correction procedure will lengthen our study excessively. Consequently, we estimate Equation 9 to calculate the short-term substitutionary elasticity of the variables. We also estimate the significance of this estimated parameter by bootstrapping simulation.

\section{Empirical results}

\subsection{Linear Granger causality}

To test the linear causal effects of the oil price changes on the macroeconomic and financial market variables, we estimate the bias-corrected LSDV model presented in the previous section. It is worth noting that with regard to Hamilton (2011), which indicates that 3-4 quarters of lag orders are not sufficient to show the effects of oil price shocks, we start with a 24-month lag and use the Akaike Information Criterion (AIC) to choose the optimum lag order. Tables 5-6 demonstrate such results. As shown in Table 5, oil price movements Granger cause almost all of the variables.

\section{$<$ TABLE 5 ABOUT HERE $>$}

The results presented in Table 5 are identical across net oil-consumer and net oilproducer countries in two cases. First, $O P$ Granger causes $I P, R E R$ and $S P$ in both panels. These findings are consistent with Cunado and Perez de Gracia (2005), Dissou (2010), Jiménez-Rodríguez (2008), Jimenez-Rodriguez and Sanchez (2009) and Papapetrou (2001). Second, there is no evidence confirming the causal effects of oil price movements on CPI. This finding appears to contradict earlier studies, which generally conclude the inflationary effects of oil price shocks. However, there is other evidence that may explain our results. For instance, Korhonen and Ledyaeva (2010) argue that economic activity in oil-producer countries suffers from the indirect effects of positive oil price shocks. They note that such indirect effects in oil-consumer countries are more heterogeneous. Given their outcomes, it is possible that a panel data model, which covers a set of net oil-consumer and net oil-producer countries, provides such results. Conversely, Cunado and Perez de Gracia (2005) show that oil price shocks in local currencies exhibit stronger effects on CPI. Anyhow, where our findings in rejecting the causal effects of global oil price changes on CPI may indicate heterogeneous responses to global oil price changes across different countries, we require further consideration to clarify this issue.

The results presented in Table 5 suggest that $O P$ exhibits adverse causal effects across both net oil-consumer and net oil-producer countries. First, OP Granger-causes MA in net oilproducer countries while we cannot reject the null of no causality in net oil-consumer countries. This finding at least provides a conclusion for the existing mixed evidence on monetary responses to oil price changes. To nominate such ambiguity, it is enough to see where Bernanke et al. (1997) suggest applying monetary policy to eliminate the recessionary effects of oil price shocks, Hamilton and Herrera (2004) cast doubt on the effectiveness of such a policy. Abderrezak (2005) finds no evidence suggesting causal linear effects of the oil price movements on the money supply in Algeria. Second, $O P$ Granger causes $I R$ in net oilconsumer countries, but not net oil-producers. The former is in agreement with Papapetrou (2001) while the latter is consistent with Lowinger et al. (1985), which states that only very 
large increases in oil price affect interest rates. Overall, it would appear that oil price changes greatly affect most parts of the macroeconomy in net oil-producer countries. In contrast, global oil price changes affect the financial markets of net oil-consumer countries more significantly.

\section{$<$ TABLE 6 ABOUT HERE $>$}

Table 6 details the inverse causal relationship between $O P$ and other variables. An important point is that as we have employed global oil price movements, we do not expect that changes in any of our domestic variables cause significant movements in global oil prices. The results indicate that we cannot reject the null hypothesis of no causality for CPI and $I R$ in both panels. These findings contradict Arora (2011), Arora and Tanner (2013) and Askari and Krichene (2010), which support the existence of interest rate effects on oil price changes. Additionally, $S P$ is not Granger caused by $O P$ in net oil-producer countries. All remaining variables significantly Granger cause oil price movements. Based on the results in Table 6, it is clear that financial markets in net oil-producer countries have no effect on oil price movements unlike net oil-consumer countries.

\subsection{Elasticity}

We use the bias-corrected LSDV model again to estimate the oil price elasticity of macroeconomic and financial market variables and consider the significance of the parameters through bootstrapping simulation. Tables 7-8 present the results.

As shown, there are some similarities and differences in net oil-consumer and net oilproducer countries in terms of the estimated elasticity values. For example, changes in $R E R$ and $S P$ are elastic in both panels, such that $10 \%$ increase in $O P$ reduces $R E R$ by $0.3 \%$ and $0.4 \%$ in net oil-consumer and net oil-producer countries, respectively. These results confirm the findings of our causality tests. Furthermore, the results concur with Dissou (2010), who shows that a $20 \%$ increase in the global prices of oil products causes an appreciation of the aggregate real exchange rate by $0.4 \%$. Our reported negative sign for $R E R$ elasticity is consistent with El-Sharif et al. (2005). They show that exchange rate returns negatively correlate with oil and gas share price returns. We also find that a $10 \%$ increase in $O P$ raises $S P$ by only $0.3 \%$ in net oil-consumer countries and $1.3 \%$ in net oil-producer countries. These results are also consistent with El-Sharif et al. (2005).

However, the differences in results between the two panels appear economically sensible. To start with, the oil price substitutionary elasticity of CPI is not significant in net oil-consumer countries, and although very small, statistically significant in net oil-producer countries. Next, in net oil-consumer countries, a $10 \%$ increase in OP causes $M A$ and IR to change by $-0.1 \%$ and $0.4 \%$, respectively, whereas such causal effects are not statistically significant in net oil-producer countries. The negative sign of MP elasticity supports the findings of Cologni and Manera (2008) in recommending a contractionary monetary policy to control the inflationary effects of unexpected oil price shocks. It is apparent that most net oilconsumer countries have earnestly applied this policy during the last few decades.

\section{$<$ TABLE 7 ABOUT HERE $>$}

Comparing the results between the two panels, the macroeconomy and financial markets in net oil-consumer countries are generally more sensitive to changes in global oil price than net oil-producers. In net oil-producer countries, however, only the macroeconomy is sensitive to global oil price changes. With the exception of CPI, all other macroeconomic variables in net oil-consumer countries are sensitive to the oil price changes. Finally, other 
than the strong elasticity of $I R$ in net oil-consumer countries and its insignificant elasticity in net oil-producer countries, we conclude the stronger sensitivity of financial markets to global oil price changes in net oil-consumer countries.

\section{$<$ TABLE 8 ABOUT HERE $>$}

\section{Conclusion}

It is generally expected that oil price changes affect the economies of both net oil-consumer and net oil-producer countries, but in opposite directions. For instance, a significant reduction in oil prices may benefit the former and harm the latter, and vice versa for oil price increases. However, our findings suggest behaviour even more diverse in relation to oil price changes. To compare the dependency of the macroeconomies and financial markets of net oil-producer and net oil-consumer countries to oil price movements, we employ panel linear Granger causality test and substitutionary oil price elasticity. Using the consumer price index, industrial production (as a proxy for economic activity), the real exchange rate and monetary aggregates as selected macroeconomic indicators, and share prices and short-term real interest rates as financial market indicators, we find that the macroeconomies of net oilproducer countries are more dependent on oil price movements than those of net oilconsumers. This is due to the significant causal effects of global oil price changes on industrial production, the real exchange rate, monetary aggregates, and the significant elasticity of the consumer price index in net oil-producer countries. This contrasts strongly with the situation in net oil-consumer countries. In contrast, the strong effects of global oil price changes on share prices and short-term real interest rates in net oil-producer countries and not net oil-consumer countries reveal that global oil price movements exert stronger effects on the financial markets in the former.

Our findings clearly reveal some similarities and differences between net oil-producer and net oil-consumer countries in relation to oil price movements. For both panels, there is a bi-directional relationship between oil price movements and industrial production as well as with the real exchange rate. However, there is no evidence confirming Granger causality between global oil price changes and the consumer price index. Lastly, the short-term interest rate does not Granger-cause oil price movements in either set of countries. Apart from the zero value of the oil price elasticity of industrial production in net oil-producer countries, all other elasticity values confirm these findings.

We also obtain some other interesting findings. First, monetary aggregate and oil price movements exhibit bi-directional causality among net oil-producer countries, whereas we only observe one-way causation running from monetary aggregates to oil price changes in net oil-consumer countries. Second, there is no causality between oil price changes and shortterm real interest rates in net oil-producer countries, although oil price changes do affect short-term real interest rates in net oil-consumer countries. Finally, oil price movements and share prices exhibit a bi-directional relationship in net oil-consumer countries, running from the oil price to share prices in net oil-producers.

In terms of policy implications, our findings suggest that policy in net oil-producer countries will differ markedly from that in net oil-consumer countries. The positive responses of monetary aggregates to global oil price changes in net oil-producer countries indicates that these countries will seek monetary policy as a rapid-acting response to control for the inflationary and other effects of oil price changes. We find that oil price changes cause monetary aggregates to rise. One scenario in explaining the subsequent effects of growth in monetary aggregates is that when they increase, consumer purchasing power may also increase, placing additional pressure on aggregate demand. If not matched by an equivalent increase in aggregate supply, inflation will increase. Our significant positive value of the 
substitutionary elasticity of the consumer price index in net oil-producer countries, confirms the short-term impact on inflation.

However, this is not the case in net oil-consumer countries. Indeed, the significant influences of oil price changes on short-term real interest rates in net oil-consumer countries demonstrates that these countries will approach policy primarily through taking control of short-term real interest rates and attempting to switch investment from the short to the longterm. The lack of evidence supporting the existence of oil price changes on monetary aggregates or the consumer price index in these same countries rejects the assumption of switching short-term investment to the commodity market. As further study, we suggest considering the possible non-linear causation of oil price changes as well as examining the existence of any asymmetric relationships. The analysis of causation in domestic oil prices would also be a useful extension of this research.

\section{References}

Abderrezak, A. (2005), 'Oil price shocks—money supply causality: Some evidence from Algeria', The Journal of North African Studies, 10 (2), pp. 173-181.

Abu-Bader, S., and Abu-Qarn, A.S. (2008), 'Financial development and economic growth: The Egyptian experience’, Journal of Policy Modeling, 30 (5), pp. 887-898.

Anderson, T.W., and Hsiao, C. (1982), 'Formulation and estimation of dynamic models using panel data', Journal of Econometrics, 18 (1), pp. 47-82.

Apergis, N., and Miller, S.M. (2009), 'Do structural oil-market shocks affect stock prices?', Energy Economics, 31 (4), pp. 569-575.

Arellano, M., and Bond, S. (1991), 'Some tests of specification for panel data - Monte Carlo evidence and an application to employment equations', Review of Economic Studies, 58 (2), pp. 277-297.

Arora, V. (2011), 'Asset value, interest rates and oil price volatility’, Economic Record, 87 (1), pp. 45-55.

Arora, V., and Tanner, M. (2013), 'Do oil prices respond to real interest rates?', Energy Economics, 36, pp. 546-555.

Askari, H., and Krichene, N. (2010), ‘An oil demand and supply model incorporating monetary policy’, Energy, 35 (5), pp. 2013-2021.

Ayhan Kapusuzoglu, M.B.K. (2011), 'An analysis of the relationships between financial indicators and energy prices among the OECD countries', International Journal of Business and Social Science, 2 (21), pp. 258274.

Balke, N.S., Brown, S.P.A., and Yucel, M.K. (2002), 'Oil price shocks and the U.S. economy: Where does the asymmetry originate?’, The Energy Journal, 23 (3), pp. 27-40.

Banca d'Italia (2013), http://bip.bancaditalia.it.

Bernanke, B.S., Gertler, M., Watson, M., Sims, C.A., and Friedman, B.M. (1997), 'Systematic monetary policy and the effects of oil price shocks', Brookings Papers on Economic Activity, 1, pp. 91-157.

Biswas, J. (2008), 'Does finance lead to economic growth?: an empirical assessment of 12 Asian economies', Margin: the journal of applied economic research, 2 (3), pp. 229-246.

Blundell, R.W. (1998), 'Initial conditions and moment restrictions in dynamic panel data models', Journal of Econometrics, 87 (1), pp. 115-143.

Bohi, D.R. (1991), 'On the macroeconomic effects of energy price shocks', Resources and Energy, 13 (2), pp. 145-162

Boulila, G., and Trabelsi, M. (2004), 'The causality issue in the finance and growth nexus: empirical evidence from Middle East and North African countries', Review of Middle East economics and finance, 2 (2), pp. 123-138

Bruno, G.S.F. (2005), 'Approximating the bias of the LSDV estimator for dynamic unbalanced panel data models', Economics letters, 87 (3), pp. 361-366.

Bun, M.J.G., and Kiviet, J.F. (2003), 'On the diminishing returns of higher-order terms in asymptotic expansions of bias', Economics letters, 79 (2), pp. 145-152.

Choi, I. (2001), 'Unit root tests for panel data', Journal of International Money and Finance, 20 (2), pp. 249272.

Ciner, C. (2001), 'Energy shocks and financial markets: nonlinear linkages’, Studies in Nonlinear Dynamics and Econometrics, 5 (3), pp. 203-212.

Cologni, A., and Manera, M. (2008), 'Oil prices, inflation and interest rates in a structural cointegrated VAR model for the G-7 countries’, Energy Economics, 30 (3), pp. 856-888. 
Cunado, J., and Perez de Gracia, F. (2005), 'Oil prices, economic activity and inflation: evidence for some Asian countries', The Quarterly Review of Economics and Finance, 45 (1), pp. 65-83.

De Nederlandsche Bank (2013), http://www.statistics.dnb.nl.

Deutsche Bundesbank Retrieved (2013), http://www.bundesbank.de.

Dissou, Y. (2010), 'Oil price shocks: Sectoral and dynamic adjustments in a small-open developed and oilexporting economy’, Energy Policy, 38 (1), pp. 562-572.

El-Sharif, I., Brown, D., Burton, B., Nixon, B., and Russell, A. (2005), 'Evidence on the nature and extent of the relationship between oil prices and equity values in the UK', Energy Economics, 27 (6), pp. 819-830.

Elmi, Z., and Jahadi, M. (2011), 'Oil price shocks and economic growth: Evidence from OPEC and OECD', Australian Journal of Basic and Applied Sciences, 5(6), pp. 627-635.

Finn, M.G. (2000), 'Perfect competition and the effects of energy price increases on economic activity', Journal of Money, Credit and Banking, 32 (3), pp. 400-416.

Granger, C.W.J. (1969), 'Investigating causal relations by econometric models and cross-spectral methods', Econometrica, 37 (3), pp. 425-438.

Guilkey, D.K., and Salemi, M.K. (1982), 'small sample properties of three tests for Granger causal ordering in a bivariate stochastic system', The Review of Economics and Statistics, 64 (4), pp. 668-680.

Hamilton, J.D. (2011), 'Nonlinearities and the macroeconomic effects of oil prices', Macroeconomic Dynamics, 15 (3), pp. 364-378.

Hamilton, J.D., and Herrera, A.M. (2004), 'Oil shocks and aggregate macroeconomic behavior: The role of monetary policy’, Journal of Money, Credit and Banking, 36 (2), pp. 265-286.

Jiménez-Rodríguez, R. (2008), 'The impact of oil price shocks: Evidence from the industries of six OECD countries', Energy Economics, 30 (6), pp. 3095-3108.

Jiménez-Rodríguez, R. (2011), 'Macroeconomic structure and oil price shocks at the industrial level', International Economic Journal, 25 (1), pp. 173-189.

Jimenez-Rodriguez, R., and Sanchez, M. (2009), 'Oil shocks and the macroeconomy: a comparison across high oil price periods’, Applied Economics Letters, 16 (16), pp. 1633-1638.

Juessen, F., and Linnemann, L. (2010) Estimating Panel VARs from Macroeconomic Data: Some Monte Carlo Evidence and an Application to OECD Public Spending Shocks (Germany: SFB 823).

Keane, M.P., and Prasad, E.S. (1996), 'The employment and wage effects of oil price changes: A sectoral analysis', The Review of Economics and Statistics, 78 (3), pp. 389-400.

Korhonen, I., and Ledyaeva, S. (2010), 'Trade linkages and macroeconomic effects of the price of oil', Energy Economics, 32(4), pp. 848-856.

Lee, K., and Ni, S. (2002), 'On the dynamic effects of oil price shocks: a study using industry level data', Journal of Monetary Economics, 49 (4), pp. 823-852.

Lowinger, T.C., Wihlborg, C., and Willman, E.S. (1985), 'OPEC in world financial markets: Oil prices and interest rates’, Journal of International Money and Finance, 4 (2), pp. 253-266.

Moon, H.R., and Phillips, P.C.B. (1999), 'Linear regression limit theory for nonstationary panel data', Econometrica, 67 (5), pp. 1057-1111.

Mork, K.A., Olsen, O., and Mysen, H.T. (1994), 'Macroeconomic responses to oil price increases and decreases in seven OECD countries’, Energy Journal, 15 (4), pp. 19-35.

Nandha, M., and Brooks, R. (2009), 'Oil prices and transport sector returns: an international analysis', Review of Quantitative Finance and Accounting, 33 (4), pp. 393-409.

Organization for Economic Co-operation and Development (OECD) (2013), http://stats.oecd.org.

Papapetrou, E. (2001), 'Oil price shocks, stock market, economic activity and employment in Greece', Energy Economics, 23(5), pp. 511-532.

Park, J., and Ratti, R.A. (2008), 'Oil price shocks and stock markets in the U.S. and 13 European countries', Energy Economics, 30 (5), pp. 2587-2608.

Phillips, P.C.B., and Moon, H.R. (2000), Nonstationary panel data analysis: an overview of some recent developments', Econometric Reviews, 19 (3), pp. 263-286.

Portal de Financas (2013), http://portaldefinancas.com.

The World Bank (2013), http://data.worldbank.org.

Sanchez, B., and Hassan, M.K. (2011), 'Financial development and economic growth: new evidence from panel data', The Quarterly Review of Economics and Finance, 51 (1), pp. 88-104.

Schubert, S.F., and Turnovsky, S.J. (2011), 'The impact of oil prices on an oil-importing developing economy', Journal of Development Economics, 94 (1), pp. 18-29.

Wolde-Rufael, Y. (2009), 'Coal consumption and economic growth revisited', Applied Energy, 87 (1), pp. 160167. 
Table 1. Oil consumption and production share of GDP in sample countries (1976-2011)

\begin{tabular}{|c|c|c|c|c|}
\hline Country & $\begin{array}{c}\text { Oil consumption } \\
\text { ('000 barrels/day) }\end{array}$ & $\begin{array}{c}\text { Oil production } \\
\text { ('000 barrels/day) }\end{array}$ & $\begin{array}{c}\text { Average net oil } \\
\text { consumption share of } \\
\text { GDP }(\%)\end{array}$ & $\begin{array}{c}\text { Average net oil } \\
\text { production share of } \\
\text { GDP (\%) }\end{array}$ \\
\hline Brazil & $984-2,629$ & $173-2,193$ & 1.89 & $\ldots$ \\
\hline Denmark & 176-326 & $4-390$ & 0.80 & $\ldots$ \\
\hline Germany & $2,362-3,341$ & $\ldots$ & 2.10 & $\ldots$ \\
\hline Italy & $1,532-1,976$ & $27-127$ & 2.42 & $\ldots$ \\
\hline Netherlands & $610-1,122$ & $\ldots$ & 3.09 & $\ldots$ \\
\hline Sweden & $305-564$ & $\ldots$ & 2.21 & $\ldots$ \\
\hline USA & $15,235-20,802$ & $6,734-10,580$ & 1.66 & $\ldots$ \\
\hline Canada & $1,540-2,298$ & $1,598-3,522$ & $\ldots$ & 0.72 \\
\hline Norway & $176-235$ & $279-3,418$ & $\ldots$ & 11.57 \\
\hline Mexico & $730-2,030$ & $894-3,766$ & $\ldots$ & 4.55 \\
\hline
\end{tabular}

Source: IEA and World Bank.

Table 2. Variables

\begin{tabular}{cll}
\hline Name & & Description \\
\cline { 1 - 1 } OP & & Global oil price \\
IP & Industrial production \\
CPI & Consumer price index \\
MA & Monetary aggregate \\
RER & Real exchange rate \\
SP & Share price \\
IR & Short-term real interest rate \\
\hline
\end{tabular}


Table 3. Panel unit root test for the variables in levels and first differences

\begin{tabular}{|c|c|c|c|c|c|c|c|c|}
\hline \multirow{3}{*}{ Variable } & \multicolumn{4}{|c|}{ Fisher-type ADF } & \multicolumn{4}{|c|}{ IPS } \\
\hline & \multicolumn{2}{|c|}{ Constant } & \multicolumn{2}{|c|}{ Trend } & \multicolumn{2}{|c|}{ No trend } & \multicolumn{2}{|c|}{ Trend } \\
\hline & P statistic & p-value & P statistic & p-value & t-bar & p-value & t-bar & p-value \\
\hline CPI & 11.6928 & 0.9262 & 21.2389 & 0.3832 & -0.3102 & 1.0000 & -1.4195 & 0.7277 \\
\hline RER & 107.8673 & 0.0000 & 53.9184 & 0.4624 & -3.9392 & 0.0000 & -2.6756 & 0.0001 \\
\hline MA & 0.6048 & 1.0000 & 5.0252 & 0.0001 & 6.1873 & 1.0000 & 1.0616 & 1.0000 \\
\hline IP & 10.9837 & 0.9466 & 75.6517 & 0.0000 & -1.2064 & 0.8866 & -2.9287 & 0.0000 \\
\hline IR & 13.0385 & 0.8757 & 38.4749 & 0.0077 & -1.2864 & 0.8164 & -2.7238 & 0.0000 \\
\hline SP & 2.3427 & 1.0000 & 9.2929 & 0.9793 & -0.1270 & 1.0000 & -1.8381 & 0.1206 \\
\hline OP & 4.8110 & 0.9998 & 28.0935 & 0.1072 & -0.9054 & 0.9898 & -2.6777 & 0.0000 \\
\hline DCPI & 670.6648 & 0.0000 & 667.2005 & 0.0000 & -16.4909 & 0.0000 & -16.6190 & 0.0000 \\
\hline DMA & 694.0444 & 0.0000 & 692.1074 & 0.0000 & -14.2574 & 0.0000 & -15.4447 & 0.0000 \\
\hline DIP & 720.8731 & 0.0000 & 720.8731 & 0.0000 & -27.1242 & 0.0000 & -27.1331 & 0.0000 \\
\hline DIR & 720.8731 & 0.0000 & 720.8731 & 0.0000 & -15.4823 & 0.0000 & -15.4701 & 0.0000 \\
\hline DSP & 720.8731 & 0.0000 & 720.8731 & 0.0000 & -15.6516 & 0.0000 & -15.6707 & 0.0000 \\
\hline DOP & 720.8731 & 0.0000 & 720.8731 & 0.0000 & -12.8518 & 0.0000 & -12.8396 & 0.0000 \\
\hline
\end{tabular}

Notes: CPI, RER, MA, IP, IR, SP and OP indicate consumer price index, real exchange rate, monetary aggregate, industrial production, short-term interest rate, share price and oil price, respectively. " $D$ " indicates the first difference. P-values show the probability of the existence of the unit root (null hypothesis).

Table 4. Panel unit root test for the logarithms of the variables in levels and first differences

\begin{tabular}{|c|c|c|c|c|c|c|c|c|}
\hline \multirow{3}{*}{ Variable } & \multicolumn{4}{|c|}{ Fisher-type ADF } & \multicolumn{4}{|c|}{ IPS } \\
\hline & \multicolumn{2}{|c|}{ Constant } & \multicolumn{2}{|c|}{ Trend } & \multicolumn{2}{|c|}{ No trend } & \multicolumn{2}{|c|}{ Trend } \\
\hline & P statistic & p-value & P statistic & p-value & t-bar & p-value & t-bar & p-value \\
\hline LNCPI & 625.3032 & 0.0000 & 78.3469 & 0.0000 & -9.5194 & 0.0000 & -2.2595 & 0.0436 \\
\hline LNRER & 109.6133 & 0.0000 & 20.6842 & 0.4159 & -3.0183 & 0.0000 & -2.1814 & 0.0083 \\
\hline LNMA & 36.0673 & 0.0151 & 25.6360 & 0.1782 & -1.7689 & 0.1945 & -1.6877 & 0.3085 \\
\hline LNIP & 17.5089 & 0.6197 & 85.0365 & 0.0000 & -1.6192 & 0.3665 & -3.1389 & 0.0000 \\
\hline LNIR & 2.3538 & 1.0000 & 8.9033 & 0.9840 & 0.7301 & 1.0000 & -1.0059 & 0.9759 \\
\hline LNSP & 67.7872 & 0.0000 & 65.5638 & 0.0000 & -1.7980 & 0.2460 & -2.7075 & 0.0000 \\
\hline LNOP & 6.5507 & 0.9979 & 34.0636 & 0.0257 & -1.0858 & 0.9490 & -2.8415 & 0.0000 \\
\hline DLNCPI & 693.7707 & 0.0000 & 696.6657 & 0.0000 & -15.6902 & 0.0000 & -17.8183 & 0.0000 \\
\hline DLNRER & 720.8731 & 0.0000 & 720.8731 & 0.0000 & -16.5112 & 0.0000 & -16.6683 & 0.0000 \\
\hline DLNMA & 720.8731 & 0.0000 & 706.5190 & 0.0000 & -17.3064 & 0.0000 & -17.4158 & 0.0000 \\
\hline DLNIP & 720.8731 & 0.0000 & 720.8731 & 0.0000 & -28.0221 & 0.0000 & -28.0526 & 0.0000 \\
\hline DLNIR & 705.3003 & 0.0000 & 694.8344 & 0.0000 & -11.9881 & 0.0000 & -12.0337 & 0.0000 \\
\hline DLNSP & 711.4782 & 0.0000 & 708.8134 & 0.0000 & -15.5644 & 0.0000 & -15.6226 & 0.0000 \\
\hline DLNOP & 720.8731 & 0.0000 & 720.8731 & 0.0000 & -14.5203 & 0.0000 & -14.5000 & 0.0000 \\
\hline
\end{tabular}

Notes: CPI, RER, MA, IP, IR, SP and OP indicate consumer price index, real exchange rate, monetary aggregate, industrial production, short-term interest rate, share price and oil price, respectively. "D" and "LN" indicate the first difference and logarithm, respectively. P-values show the probability of the existence of the unit root (null hypothesis). 
Table 5. Panel linear causality test results

\begin{tabular}{|c|c|c|c|c|c|c|}
\hline \multirow[b]{2}{*}{ Causality } & \multicolumn{3}{|c|}{ Net oil-consumer countries } & \multicolumn{3}{|c|}{ Net oil-producer countries } \\
\hline & $\begin{array}{l}\text { Test statistic } \\
\text { (Chi-square) }\end{array}$ & p-value & Result & $\begin{array}{l}\text { Test statistic } \\
\text { (Chi-square) }\end{array}$ & p-value & Result \\
\hline$\triangle O P \rightarrow \triangle C P I$ & 0.51 & 0.9730 & Non-causality & 4.38 & 0.3569 & Non-causality \\
\hline$\Delta O P \rightarrow \Delta I P$ & 37.82 & 0.0000 & Causality & 10.08 & 0.0391 & Causality \\
\hline$\triangle O P \rightarrow \triangle R E R$ & 124.25 & 0.0000 & Causality & 65.10 & 0.0000 & Causality \\
\hline$\Delta O P \rightarrow \triangle M A$ & 6.07 & 0.1942 & Non-causality & 22.94 & 0.0001 & Causality \\
\hline$\Delta O P \rightarrow \Delta S P$ & 43.79 & 0.0000 & Causality & 8.44 & 0.0768 & Causality \\
\hline$\Delta O P \rightarrow \Delta I R$ & 15.63 & 0.0036 & Causality & 0.17 & 0.9965 & Non-causality \\
\hline
\end{tabular}

Note: p-values estimated by bootstrapping simulation.

Table 6. Inverse panel linear causality test results

\begin{tabular}{|c|c|c|c|c|c|c|}
\hline \multirow[b]{2}{*}{ Causality } & \multicolumn{3}{|c|}{ Net oil-consumer countries } & \multicolumn{3}{|c|}{ Net oil-producer countries } \\
\hline & $\begin{array}{l}\text { Test statistic } \\
\text { (Chi-square) }\end{array}$ & p-value & Result & $\begin{array}{l}\text { Test statistic } \\
\text { (Chi-square) }\end{array}$ & p-value & Result \\
\hline$\triangle C P I \rightarrow \triangle O P$ & 0.86 & 0.9299 & Non-causality & 1.94 & 0.7471 & Non-causality \\
\hline$\Delta I P \rightarrow \triangle O P$ & 8.51 & 0.0744 & causality & 7.82 & 0.0986 & causality \\
\hline$\triangle R E R \rightarrow \triangle O P$ & 15.77 & 0.0013 & causality & 424.27 & 0.0000 & causality \\
\hline$\triangle M A \rightarrow \triangle O P$ & 13.82 & 0.0079 & causality & 16.87 & 0.0020 & causality \\
\hline$\Delta S P \rightarrow \triangle O P$ & 207.33 & 0.0000 & causality & 4.83 & 0.3054 & Non-causality \\
\hline$\Delta I R \rightarrow \Delta O P$ & 2.31 & 0.6789 & Non-causality & 2.34 & 0.6727 & Non-causality \\
\hline
\end{tabular}

Note: p-values estimated by bootstrapping simulation.

Table 7. Oil price elasticity (net oil-consumer countries)

\begin{tabular}{lccc}
\hline Elasticity & Value & 95\% confidence interval & S.E. \\
\hline $\mathrm{E}_{\mathrm{CPI}}$ & 0.0053 & $-0.0070-0.0175$ & 0.0062 \\
$\mathrm{E}_{\mathrm{IP}}$ & $0.0260^{*}$ & $0.0167-0.0352$ & 0.0047 \\
$\mathrm{E}_{\mathrm{RER}}$ & $-0.0383^{*}$ & $-0.0512--0.0253$ & 0.0066 \\
$\mathrm{E}_{\mathrm{MA}}$ & $-0.0126^{* *}$ & $-0.0224--0.0028$ & 0.0050 \\
$\mathrm{E}_{\mathrm{SP}}$ & $0.0384^{*}$ & $0.0128-0.0640$ & 0.0130 \\
$\mathrm{E}_{\mathrm{IR}}$ & $0.0460^{*}$ & $0.0108-0.0812$ & 0.0179 \\
\hline Notes: & and $* *$ significant at the 1 and 5 per cent levels, respectively. \\
P-values estimated by bootstrapping simulation.
\end{tabular}

Table 8. Oil price elasticity (net oil-producer countries)

\begin{tabular}{lccc}
\hline Elasticity & Value & 95\% confidence interval & S.E. \\
\hline $\mathrm{E}_{\mathrm{CPI}}$ & $0.0098^{*}$ & $0.0037-0.0159$ & 0.0031 \\
$\mathrm{E}_{\mathrm{IP}}$ & 0.0137 & $-0.0051-0.0324$ & 0.0095 \\
$\mathrm{E}_{\mathrm{RER}}$ & $-0.0430^{*}$ & $-0.0589--0.0270$ & 0.0081 \\
$\mathrm{E}_{\mathrm{MA}}$ & -0.0084 & $-0.0303-0.0135$ & 0.0111 \\
$\mathrm{E}_{\mathrm{SP}}$ & $0.1315^{*}$ & $0.0756-0.1874$ & 0.0285 \\
$\mathrm{E}_{\mathrm{IR}}$ & 0.0306 & $-0.0159-0.0770$ & 0.0237 \\
\hline
\end{tabular}

Notes: * significant at the 1 per cent level. P-values estimated by bootstrapping simulation. 
Figure 1. Determination of net oil-producer and net oil-consumer countries among oilproducer/consumer countries (1976-2011)

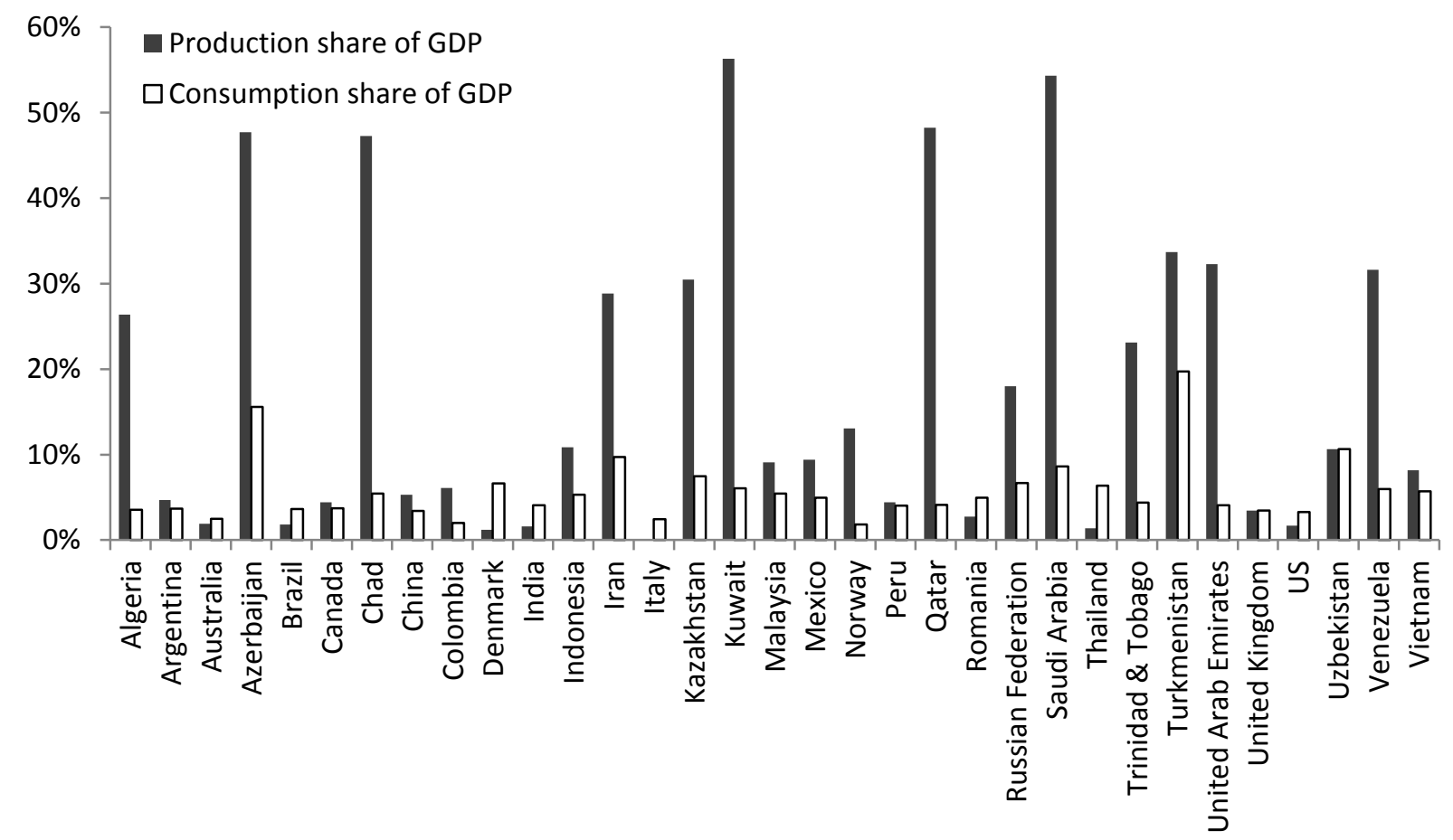

Source: Calculated using IEA and World Bank data 